\title{
Manifestation of lymphoma expansion following lymphatic drainage on ${ }^{18}$ F-FDG PET/CT
}

\author{
Silvia A. Eshuis • Rudi A. J. O. Dierckx • \\ Paul J. H. van Snick • Riemer H. J. A. Slart • \\ Andor W. J. M. Glaudemans
}

Received: 27 January 2011 /Accepted: 6 April 2011 /Published online: 7 May 2011

(C) The Author(s) 2011. This article is published with open access at Springerlink.com

\begin{abstract}
${ }^{18}$ F-fluorodeoxyglucose (FDG) positron emission tomography (PET) imaging is strongly recommended in patients with diffuse large B-cell lymphomas (DLBCL), which are routinely highly FDG avid, for adequate disease staging [1]. The mean standardized uptake value (SUV) can be used to distinguish aggressive from indolent lymphoma variants [2]. PET scanning is a reliable method for the diagnosis of DLBCL compared with the reference method immunohistology [3].

We present a case of a 70-year-old female patient who presented to the hospital with progressive swelling, pain and loss of sensibility in her right lower limb. Nine months earlier she had been diagnosed with DLBLC, localized in the lungs, mediastinum and mesenterium for which she was treated with rituximab plus cyclophosphamide, doxorubicin, vincristine and prednisone (R-CHOP) chemotherapy. ${ }^{18}$ F-FDG PET/CT scanning was performed for restaging of lymphoma disease in this patient.

${ }^{18}$ F-FDG PET/CT showed an extensive lesion in the right lower limb, with extremely high avidity for FDG, corresponding with tumour mass in muscular tissue on the low-dose CT (figure). It was spreading upwards, following
\end{abstract}

S. A. Eshuis - R. A. J. O. Dierckx • P. J. H. van Snick •

R. H. J. A. Slart $\cdot$ A. W. J. M. Glaudemans $(\bowtie)$

Department of Nuclear Medicine and Molecular Imaging,

University Medical Center Groningen, University of Groningen,

Groningen, The Netherlands

e-mail: a.w.j.m.glaudemans@ngmb.umcg.nl

R. A. J. O. Dierckx

Ghent University,

Ghent, Belgium

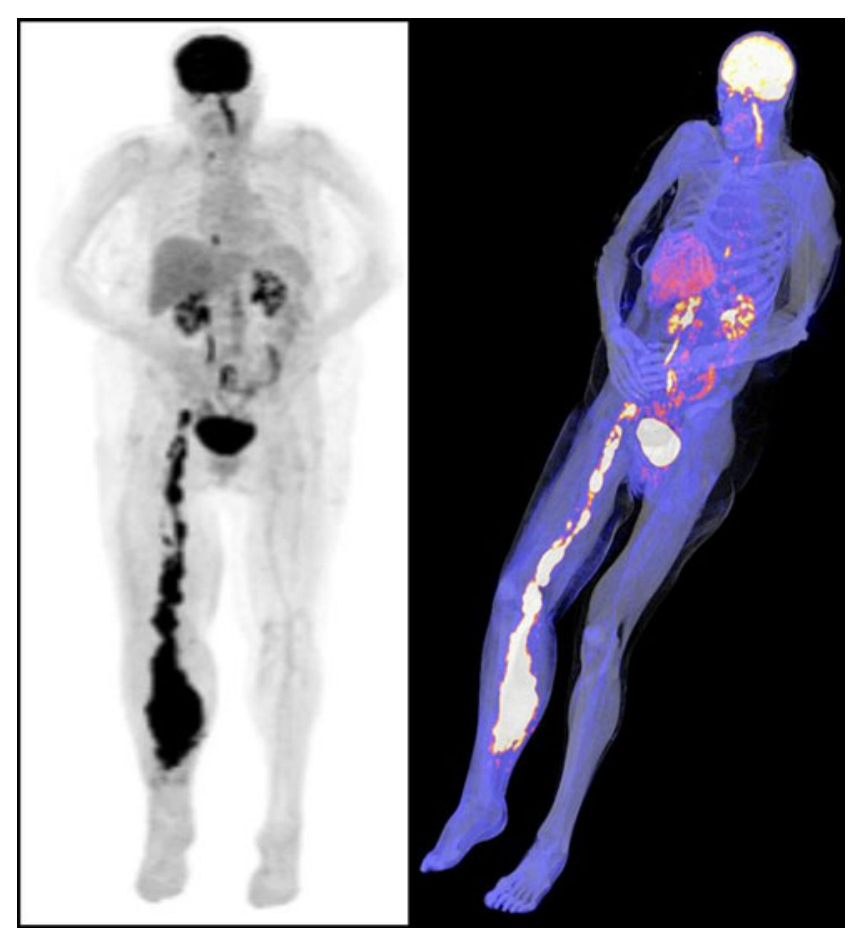

the lymphatic drainage system and surrounding vessels, up to the right groin region. The $\mathrm{SUV}_{\text {mean }}$ of this large lesion was 16.4 (calculation conforming to the EANM procedure guidelines for tumour PET imaging [4]). Further on, a lesion was detected dorsally in the right lung.

Biopsy of the swelling in the right lower limb revealed aggressive DLBCL recurrence. This aggressive form was already expected due to the high $\mathrm{SUV}_{\text {mean }}$ value. This scan 
shows how aggressive DLBCL can appear as a fast growing lymphoma with an atypical configuration by following the lymphatic drainage.

Conflicts of interest None.

Open Access This article is distributed under the terms of the Creative Commons Attribution Noncommercial License which permits any noncommercial use, distribution, and reproduction in any medium, provided the original author(s) and source are credited.

\section{References}

1. Cheson BD, Pfistner B, Juweid ME, Gascoyne RD, Specht L, Horning SJ, et al. Revised response criteria for malignant lymphoma. J Clin Oncol 2007;25:579-86.

2. Delbeke D, Stroobants S, de Kerviler E, Gisselbrecht C, Meignan M, Conti PS. Expert opinions on positron emission tomography and computed tomography imaging in lymphoma. Oncologist 2009;14 Suppl 2:30-40.

3. Friedberg JW, Chengazi V. PET scans in the staging of lymphoma: current status. Oncologist 2003;8:438-47.

4. Boellaard R, O'Doherty MJ, Weber WA, Mottaghy FM, Lonsdale MN, Stroobants SG, et al. FDG PET and PET/CT: EANM procedure guidelines for tumour PET imaging: version 1.0. Eur $\mathrm{J}$ Nucl Med Mol Imaging 2010;37:181-200. 